\title{
Papers
}

\section{Psychosocial effects of the 2001 UK foot and mouth disease epidemic in a rural population: qualitative diary based study}

Maggie Mort, Ian Convery, Josephine Baxter, Cathy Bailey

\begin{abstract}
Objectives To understand the health and social consequences of the 2001 foot and mouth disease epidemic for a rural population.

Design Longitudinal qualitative analysis.

Setting North Cumbria, the worst affected area in Britain. Sample Purposive sample of 54 respondents divided in six demographically balanced rural occupational and population groups.

Main outcome measures 3071 weekly diaries contributed over 18 months; 72 semistructured interviews (with the 54 diarists and 18 others); 12 group discussions with diarists

Results The disease epidemic was a human tragedy, not just an animal one. Respondents' reports showed that life after the foot and mouth disease epidemic was accompanied by distress, feelings of bereavement, fear of a new disaster, loss of trust in authority and systems of control, and the undermining of the value of local knowledge. Distress was experienced across diverse groups well beyond the farming community. Many of these effects continued to feature in the diaries throughout the 18 month period.

Conclusions The use of a rural citizens' panel allowed data capture from a wide spectrum of the rural population and showed that a greater number of workers and residents had traumatic experiences than has previously been reported. Recommendations for future disaster management include joint service reviews of what counts as a disaster, regular NHS and voluntary sector sharing of intelligence, debriefing and peer support for front line workers, increased community involvement in disposal site or disaster management, and wider, more flexible access to regeneration funding and rural health outreach work.
\end{abstract}

\section{Introduction}

The United Kingdom's foot and mouth disease epidemic in 2001 has been described as the most serious ever to occur in a country previously free of the disease $e^{1}$ and "a traumatic and devastating experience for all those who were affected by it ... a national crisis ... probably one of the greatest social upheavals since the war." ${ }^{2}$ Between 6.5 million and 10 million animals were slaughtered across the UK, and in north Cumbria 893 farms had confirmed infected cases, with a further 1934 having complete or partial culls of livestock, representing $70 \%$ of farms. ${ }^{34}$ Restrictions on public rights of way and advice to stay away from the countryside led to a collapse in tourist numbers and loss of recreational use of the landscape for a year. ${ }^{5}$
In the spring of 2001, the $B M J$ asked how health services were responding to the crisis. ${ }^{6}$ Immediate concerns centred on zoonosis, ${ }^{7}$ and public health clinicians raised concerns about the use of large pyres and mass burials for animal carcass disposal. ${ }^{8}$ Some contributors called for examination of the anxiety, stress, and other mental health consequences which they believed must follow: "at best, major stress and anxiety states; at worst, suicide and its consequences for families. Are these not 'human consequences', and indeed public health matters?"10 One correspondent reported that the (then) health authority in the worst affected area had been only "peripherally involved," and called for a greater public health role in managing the disaster. ${ }^{11}$

Crucially, because the epidemic was treated as an animal problem, managed by the Ministry of Agriculture, Fisheries, and Food (later Department for Environment, Food, and Rural Affairs, DEFRA), the human tragedy was not accounted for or understood. The epidemic was held to be something affecting farmers, ignoring the large numbers of other occupations and residents drawn into the crisis. For those health practitioners working in the worst affected areas, there was the familiar problem of lack of evidence. Healthcare services in north Cumbria and other severely affected areas did not record any significant increase in demand during the epidemic and subsequent months, which was taken to mean that the health and social effects of the disaster were not significant (although a retrospective study of diabetes service activity has found a possible deterioration of blood glucose control over the duration of the crisis among those affected; final results are awaited ${ }^{12}$ ).

Yet what counts as evidence in health research goes beyond the pathological and the statistical. In contrast with the NHS experience, voluntary local helplines and rural support groups were besieged with appeals for help: "health" during the crisis was more about survival and practical support than medical interventions. This apparent contradiction called for a qualitative study that could capture evidence about the impact of the disaster and processes of recovery from "on the ground" accounts collected over time. ${ }^{13}$

\section{Methods}

Study design

This large qualitative ethnographic study was underpinned by theories of expertise that distinguish between first hand, experiential, informal knowledge and the distal aggregated or formal knowledge. ${ }^{145}$ While the three official inquiries into the disease outbreak (by Anderson, the European Union, and the Royal opment of the major analytical themes appear on bmj.com 
Table 1 Occupational and residential groups included in the rural citizens' panel, and their study data

\begin{tabular}{|c|c|c|c|c|}
\hline \multirow[b]{2}{*}{ Group No } & \multirow[b]{2}{*}{ Members } & \multicolumn{3}{|c|}{ Study data } \\
\hline & & Group discussions & Interviews & Weekly diaries \\
\hline 1 & Farmers, farm workers, and their families & 2 & 9 & 601 \\
\hline 2 & Small businesses, to include tourism, arts and crafts, retail, and others & 2 & 8 & 394 \\
\hline 3 & Related agricultural workers, to include livestock hauliers, agricultural contractors, and auction market staff & 2 & 9 & 576 \\
\hline 4 & $\begin{array}{l}\text { Front line clean-up workers and managers (from DEFRA or Environment Agency), slaughter teams (temporary, } \\
\text { seconded, and permanent staff) }\end{array}$ & 2 & 7 & 380 \\
\hline 5 & Community, such as teachers, clergy, residents near disposal sites & 2 & 9 & 533 \\
\hline 6 & Health professionals, such as general practitioners, community nurses, and vets & 2 & 9 & 587 \\
\hline
\end{tabular}

DEFRA=Department for Environment, Food and Rural Affairs.

Society) had recruited established professional experts, our study recruited "lay experts" whose experiential contribution to knowledge is often overlooked. ${ }^{16-18}$

With the help of a multi-agency steering group (see appendix on bmj.com), we drew up a rural citizens' panel with a demographic and occupational sampling frame. The panel of 54 respondents was purposively sampled from six groupings identified by the steering group as affected in a range of ways in the disease outbreak (see table 1).

We developed detailed group descriptors based on age, sex, location, and occupational subsector, and forwarded these to an independent professional recruiter. Respondents' identities were released to the research team only once we were satisfied that the descriptors had been matched. The primary means of data collection was a diary designed for the purpose, which began with simple questions about health and quality of life followed by a space for free text entries of any length. This latter section became the most frequently and fully used space, with respondents writing between half a page and six pages each week. No explicit questions were asked about the disease outbreak in the diary as it was important for accounts to be led by respondents. A major advantage of diary studies is that they bring the task of data collection into the respondents' everyday world. ${ }^{19}{ }^{20}$ They offer the opportunity to study change over time and provide insight, in a direct manner, into diarists' experiences and how they perceive them. ${ }^{21}$

Initially, six group meetings were held to explain the purpose of the study and obtain respondents' signed consent to participate. Each respondent also gave an in depth interview around this time. Group meetings were reconvened at the close of diary writing, to offer feedback and gain validation of the emerging analysis (table 1).

\section{Participants}

The panel of 54 respondents was recruited between October and November 2001 (for details, see table A in appendix on bmj.com), with the first group meeting held in December, before the declaration of virus-free status and lifting of movement restrictions. All first round meetings were highly charged; for example, many of those in group 1 had hardly left their farms or workplaces for nine months, and, though they made many harrowing contributions, they were clearly relieved to meet, talk, and listen to their peers.

Diary writing began in the week of 21 December and continued over the next 18 months, during which time just three respondents chose to discontinue. Periods of "holiday" from diary writing were negotiated, and the total number of weekly diaries collected (at monthly visits to the diarists) was 3071. In recognition of respondents' time and expertise, a small fee was paid on collection of the diaries. Respondents showed strong commitment to the research, generating a unique longitudinal dataset (anonymised) for which we are negotiating consent for a public electronic archive.

\section{Analysis}

All interviews and group meetings were transcribed from audiotape; diaries were transcribed from the original (usually hand written) format. After individual researchers had read and annotated the material, all four researchers held eight "data clinics" to identify emerging themes, using a constant comparative approach. ${ }^{22-24}$ This entailed examining, comparing, and categorising data until no new categories emerged. Underpinning our analysis of the categories by the theories of knowledge mentioned above, we developed four major analytical themes. We then entered codes, categories, and themes into Atlas Ti software, where the anonymised data are held. Respondent validation of codes and themes was carried out at six subsequent group meetings.

\section{Results}

We identified four major analytical themes (altered lifescapes, trauma and recovery, trust in governance, and knowledge and place) (see table B on bmj.com for details of their supporting categories and codes). Table 2 outlines the health and social consequences identified from the data. These medium to long term health and social impacts were neither discrete nor mutually exclusive, and many respondents experienced complex, synergistic interactions of these consequences.

Altered lifescapes represents the cluster of responses that concern the disturbed relation between health and place; the changed significance of everyday places and spaces previously taken for granted in respondents' lives. Such places were radically altered during the disease crisis (see box 1 )

Table 2 Process of analysis (medium and long term effects developed from the codes)

\begin{tabular}{|c|c|c|}
\hline Effects & Health consequences & Social consequences \\
\hline \multirow{4}{*}{$\begin{array}{l}\text { Medium } \\
\text { term }\end{array}$} & \multirow{2}{*}{$\begin{array}{l}\text { Deterioration in chronic conditions and } \\
\text { diseases due to disruption in personal } \\
\text { routines and access to health services }\end{array}$} & Loss of amenity and recreation \\
\hline & & $\begin{array}{l}\text { Tensions and conflict within } \\
\text { communities }\end{array}$ \\
\hline & $\begin{array}{l}\text { Sleep disruption, flashbacks, nightmares, } \\
\text { uncontrollable emotion, loss of concentration }\end{array}$ & Increased social isolation \\
\hline & $\begin{array}{l}\text { Reported effects of pyres-headaches, } \\
\text { respiratory problems, nausea, loss of } \\
\text { physical exercise and recreation for a year }\end{array}$ & \\
\hline \multirow[t]{5}{*}{$\begin{array}{l}\text { Longer } \\
\text { term }\end{array}$} & $\begin{array}{l}\text { Sharp increase in anxiety across different } \\
\text { occupational groups }\end{array}$ & $\begin{array}{l}\text { Communities experiencing } \\
\text { permanent changes in land use }\end{array}$ \\
\hline & $\begin{array}{l}\text { Loss of confidence leading to longer term } \\
\text { stress }\end{array}$ & $\begin{array}{l}\text { Loss of confidence in ability of } \\
\text { organisations to control crises }\end{array}$ \\
\hline & $\begin{array}{l}\text { Ongoing health fears of residents living near } \\
\text { carcass disposal sites }\end{array}$ & $\begin{array}{l}\text { Loss of trust in governance and } \\
\text { decision making bodies }\end{array}$ \\
\hline & $\begin{array}{l}\text { Increased number of injuries relating to } \\
\text { handling new livestock }\end{array}$ & $\begin{array}{l}\text { Uncertainty, confusion, and lack } \\
\text { of continuity in public life }\end{array}$ \\
\hline & $\begin{array}{l}\text { Workplace health: risks and hazards (short } \\
\text { term) plus change and uncertainty (longer } \\
\text { term) leading to increased number of injuries }\end{array}$ & $\begin{array}{l}\text { Bitterness (collective and } \\
\text { individual) linked to lack of } \\
\text { resolution of pain and suffering } \\
\text { Increased sense of fragility in } \\
\text { employment }\end{array}$ \\
\hline
\end{tabular}




\section{Box 1: Altered lifescapes}

"The silence, no it gets sad sometimes when you're in here ... To be in here for a whole year, every day to see nobody ... You begin to hate the place, you being to hate the thing you love"Craftsman, small business, January 2002

"The self imposed isolation of not sending kids to school etc ... to go against the flow is very difficult ... They were not allowed to leave the house for three months. They just viewed this as a punishment imposed because they refused to let their hefted flock be culled"-Vet, March 2002

"They [schoolchildren] didn't like their farms, they didn't like their homes ... they'd say things like, 'It's spooky, there's no noise"Primary schoolteacher, February 2002

"There was no normality eh, normality had gone"-Farm worker hired as slaughterman, February 2002

Trauma and recovery groups the large body of data referring to distress, anguish, horror, and re-traumatisation but also endurance and sources of support articulated by respondents. Our definition of trauma within this context encompasses both the events and how those events were experienced by individuals and communities. Trauma is associated with the inability to fight or flee-that is, being trapped in the stressful environment and unable to take control over one's place relative to events (box 2).

Trust in governance reflects the data relating to chaos, loss of personal security, and powerlessness in the face of conflicting advice (box 3).

Knowledge and place covers the body of material concerning a "gap" between different kinds of knowledge-proximal knowledge derived from local experience and centralised or distal knowledge. For example, organisational directives were per-

\section{Box 2: Trauma and recovery}

"Taking my daughter and her friend home [from a show in Carlisle]. It was the same evening that her father's pedigree sheep were being taken to the voluntary cull. By mistake, I took them through a closed road, the sign having fallen down to the side of the grass. In the dark we went past a burning pyre only yards from the hedge separating the road and the field. We could see the charred, rigid bodies of the cows and the sparks from the fire and the smell permeating the air and the silence of the two young girls"-Community nurse, June 2003

"I was coming home very late at night, and I didn't want to talk to anybody ... I was just ignoring [my boyfriend] I wouldn't talk to him. I wouldn't phone my parents, I wouldn't phone any of my friends.... I just wanted nothing to do with anybody"Government agency field officer, February 2002

"I'll never be able to look at a cow or a sheep again without seeing blood pouring out of the hole in its head, ... maybe I will in time.... I walked, walking along the pier one night ... I did actually think about jumping in ... I felt so bad about myself"Seconded government agency field officer, February 2002

"It's a year since I went away killing. I feel a bit funny with myself today. It was our wedding anniversary on the 10th, but this sticks in my mind more"-Farm worker hired as slaughterman, March 2002

"Anything we do this weekend will be better than last year. A couple of sleepless nights as the memories come back"-Auction mart worker and farmer, April 2002

A year later (2003) she wrote: "Don't look forward to this week in the end of April. 27-28th April 2001 has awful memories"-April 2003

\section{Box 3: Trust in governance}

"What is being tested for in the surrounding streams? What exactly is classed as a danger? And if problems did arise, how would they be monitored and resolved? All these issues do tend to make you anxious"--Resident near disposal site, March 2002

"The week we lost all our animals to foot and mouth was the longest week ever. On the fourth day they came for some [dead stock] ... The driver they sent hadn't been on a machine like that for 9 years. He didn't come back. The next day they didn't come until late afternoon. There was no driver for the telescope handler.... We didn't see anyone for 2 days. I kept phoning to see what was happening. They kept saying there were no lorries. The army liaison officer kept coming out to see us. We were bothered about our next door neighbours, because they could see the [dead] cows beside the wall, they looked out onto them. The wall was cracking with the weight of the cows. On the 7th day they came"-Farmer, April 2002

ceived to be stripped of context, unable to adapt to what was happening "on the ground" and unable to mobilise stocks of local expertise. This theme also includes disruption and loss of participation in important life events such as funerals or births (box 4).

\section{Discussion}

The study shows that life after the foot and mouth disease epidemic has been accompanied by distress, feelings of bereavement, fear of a new disaster, loss of trust in authority and systems of control, and by the undermining of the value of local knowledge. Diary accounts show how reactions among those caught up in the epidemic were exacerbated by diverse factorsinfluence of location on business recovery, the burden of dealing with new regulations that demanded cultural change, fear of the epidemic returning, and the stress of living with uncertainty. But suffering was also alleviated by the sources of strength such as support networks (formal and informal) drawn on to cope with both traumatic experience and severe practical difficulties. This ambiguity is supported by other studies of disasters in sociology ${ }^{25}{ }^{26}$ and psychology, ${ }^{27}$ and implies that statutory and voluntary organisations have a more complex and enduring role after a disaster than has been understood. People who have experienced a disaster may not be sick as a result, but they need careful and appropriate support to rebuild lives and regain confidence (box 5).

\section{Box 4: Knowledge and place}

"We thought as a practice it might be nice to contact the farms and offer our support, so we did that ... One of our nurses is very very closely connected with the farming community, speaks their language, and so she had the job every morning of looking at the list and phoning people ... How far did the ripples go, and, and where did they go? Er, I mean a few years' time, I mean you won't remember why we changed those Tuesday surgeries probably ... you just did things"-General practice manager, March 2002

"G's 1st birthday ... Feel very glad I bought the video camera because, after the last year on [foot and mouth disease], I feel as if I've missed out on him growing in his first year of life, which makes me feel sad"-Livestock professional, April 2002

"Knowledge is passed down generations, it's not learned by somebody coming from nowhere into an office and reading a textbook"-Agricultural related business, June 2003 


\section{Box 5: Hidden effects}

"No [nursing] visit to a house during that period was simple. Emotions were near the surface and every day brought fresh news and concerns. I'm sure that if an audit of the medical and nursing registers were undertaken for that period, there would be little evidence of any increased formal counselling. This wasn't because it didn't happen, but because it became the norm. But what happened to all that stress and tension? Some people may have resolved their experiences, but I feel, for the majority, it was put on to the back burner and gradually buried in the day to day realities of living. This does not mean that it's gone ... Stress can also be detrimental to physical health, and it plays a large contributing part in many conditions. Yet the effect of the stress of that period will remain undocumented and unappreciated as it will be hard to allocate blame to one specific time frame"Community nurse, contribution to feedback conference October 2003

A defining feature of the foot and mouth disease epidemic was its long duration. Many respondents were exposed to repeated traumatic experience, such as slaughter or cleaning up after culls, for longer than in many other disasters. In north Cumbria the "event" lasted 12 months, to be followed, as in other affected rural areas, by distressing anniversaries ever since. The figure shows an example of how we "mapped" a respondent's reports of health and quality of life with his free text accounts of everyday events over the 18 months that he kept a diary (movement restrictions still in place during weeks 1-5).

\section{Conclusions}

The distress caused by the epidemic shapes the context in which many rural health practitioners in the UK now work. Distress is not a medical problem, however, unless it becomes pathological, when it is re-categorised as depression or post-traumatic stress disorder. If it is treated it is counted. Otherwise those who are suffering are expected to recover using their own resources and networks. ${ }^{29}$ Our results imply recommendations for change mostly in attitude and emphasis, rather than the creation of new bodies or yet more specific targets and protocols.

\section{What is already known on this topic}

The 2001 foot and mouth disease epidemic caused widespread disruption and closure of much of the British countryside for more than a year

Government sponsored inquiries concentrated on agricultural and organisational issues; academic studies on economic or rural policy issues. Little is known about the human cost of the disaster

\section{What this study adds}

The epidemic was a human tragedy, not just an animal one

Longitudinal ethnographic study shows the profound psychosocial effects of the disaster among a wide range of rural workers and residents that would not be revealed by more traditional biomedical or health research methods

After such a disaster, the responses required of health and social care services are more complex and enduring than the initial assessments based on service demand and clinical evidence may suggest

We argue for more flexibility in disaster planning and organisational emergency plans (such as less tightly prescribed steps and invariant sequences in planning), since such plans themselves carry further risks. ${ }^{30}$ Not all our study findings translate neatly into recommendations for operational change. However, we urge the authorities and agencies involved in disaster management, care, and recovery to recognise the interrelationship between traumatic experience and agency responses, undertake joint service reviews of what counts as a disaster, facilitate sharing of intelligence between the statutory health and voluntary sectors, introduce opportunities for debriefing and peer support for front line workers, make rural health outreach initiatives eligible for regeneration funding, and increase community involvement in disposal site management.

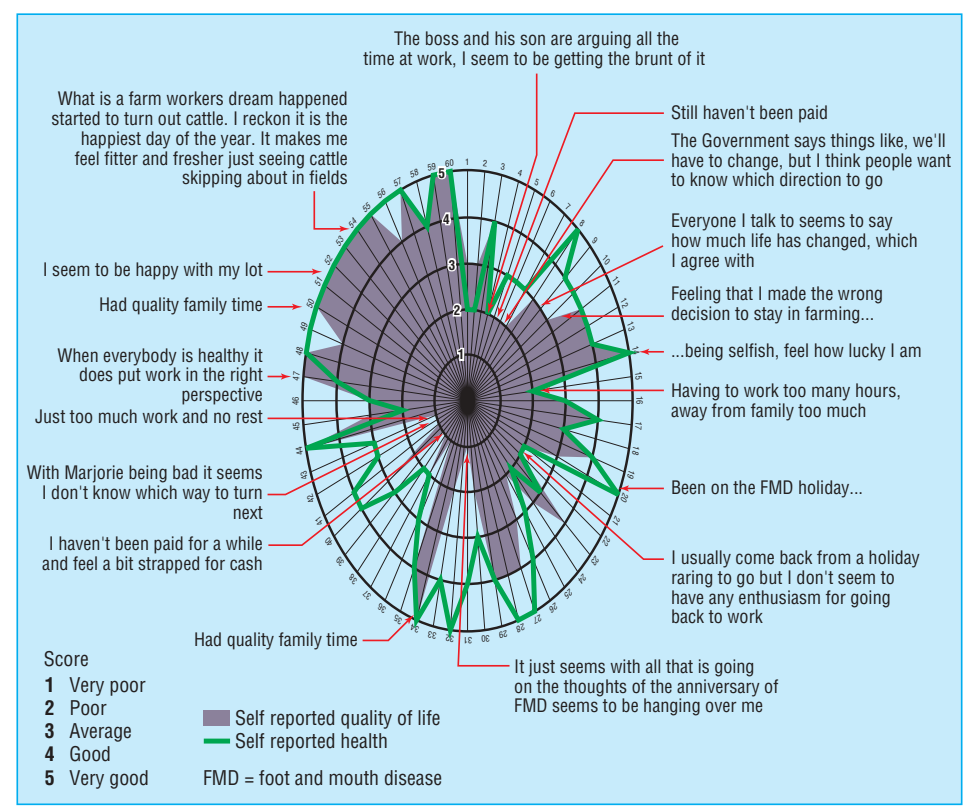

Example of a respondent's (a farm worker) diary data "mapped" from December 2001 to May 2003 
We thank all the study respondents for their commitment and contributions, the project steering group members for invaluable guidance throughout the study, Tony Gatrell and Peter Tiplady for their helpful advice at the outset, Kai Erikson for his advice and support during the analysis phase, and Carl May and Tim Burnett for comments on earlier drafts of this paper.

Contributors: MM and IC conceived and designed the study; $\mathrm{CB}, \mathrm{IC}$, and JB led the fieldwork, and all authors contributed to the analysis. MM and IC drafted the paper and all authors contributed to revision and approved final version. MM is study guarantor.

Funding: This study was undertaken by the Institute for Health Research, Lancaster University, which received funding from the Department of Health. The views expressed in the study are those of the authors and not necessarily those of the Department of Health.

Competing interests: None declared.

Ethical approval: The study was approved by both East and West Cumbria Local Research Ethics Committees.

1 Cumbria Foot \& Mouth Disease Inquiry. Inquiry report. Carlisle: Cumbria County Council, 2002

2 Anderson I. Foot and mouth disease 2001: lessons to be learned inquiry. London: Stationery Office, 2002

3 National Audit Office. The 2001 outbreak of foot and mouth disease. London: Stationery Office, 2002 (www.nao.gov.uk/publications/nao_reports/01-02/0102939.pdf).

4 European Parliament Temporary Committee on Foot-and-Mouth, PE 322.219. European Parliament resolution on measures to control foot-and-mouth disease in the European Union in 2001 and future measures to prevent and control animal diseases in the European Union. European Parliament, 2002. (Report No 2002/2153(INI), P5 TA-PROV (2002) 0614.)

5 Campbell D, Lee R. 'Carnage by computer': the blackboard economics of the 2001 foot and mouth epidemic. Social Legal Studies 2003:12:425-59.

6 Prempeh H, Smith R, Muller B. Foot and mouth disease: the human consequences. BMJ Prempeh H, Smith

7 Morton HG. Foot and mouth disease-human consequences [electronic response to Prempeh et al. Foot and mouth disease: the human consequences]. BMJ 2001 bmj.com/cgi/eletters/322/7286/565\#13243 (posted 15 Mar).

8 Gibson G. Human consequences of foot and mouth disease are more than described. BMJ 2001;322:1491.

9 Fagbo S. Re: Foot and mouth disease-human consequences [electronic response to Prempeh et al. Foot and mouth disease: the human consequences]. BMJ 2001. bmj.com/cgi/eletters/322/7286/565\#13876 (posted 16 Apr).

10 Hunter M. Public health concerns grow over foot and mouth disease. BMJ 2001;322:881.

11 Calvert N. Communicable disease control must remain at local level. BMJ 2001;323:236.
12 Sved AA, Tiplady P, Large DM. Human consequences of foot and mouth disease: a diabetes perspective. Diabetes Today 2002;5(3):75-6.

13 Pope C, Mays N. Reaching the parts other methods cannot reach. An introduction to qualitative methods in health and health services research. BMJ 1995;311:42-5.

14 Polanyi M. The tacit dimension. London: Routledge and Kegan Paul, 1967.

15 Lave J, Wenger E. Situated learning: legitimate peripheral participation. Cambridge: Cambridge University Press, 1991.

16 Kashefi E, Mort M. Grounded citizens' juries: a tool for health activism? Health Expectations 2004;7:290-304.

17 Coote A, Lenaghan J. Citizens' juries, theory into practice. London: Institute for Public Policy Research, 1997.

18 Wynne B. May the sheep safely graze? A reflexive view of the expert-lay knowledge divide. In: Lash S, Szerszyinski B, Wynne B, eds. Risk, environment and modernity: towards a new ecology. London: Sage, 1997:45-83.

19 Elliot H. The use of diaries in sociological research on health experience. Sociological Research Online 1997;2. Available from www.socresonline.org.uk/socresonline/2/2/ 7.html.

20 Verbrugge LM. Health diaries. Med Care 1980;18:73-95.

21 Jones RK. The unsolicited diary as a qualitative research tool for advanced research capacity in the field of health and research. Qual Health Res 2000;10:555-67.

22 Barnes D. An analysis of the grounded theory method and the concept of culture. Qual Health Res 1996;6:429-41.

23 Strauss A, Corbin J. Basics of qualitative research techniques and procedures for developing grounded theory. 2nd ed. London: Sage, 1998.

24 Ruston A, Clayton J, Calnan M. Patients' action during their cardiac event: qualitative study exploiting differences and modifiable factors. BMJ 1998;316:1060-5.

25 Erikson K. In the wake of the flood. London: George Unwin and Allen, 1976.

26 Erikson K. A new species of trouble. New York: W W Norton, 1994.

27 McMillen J, Smith E, Fisher R. Perceived benefit and mental health after three types of disaster. J Consult Clin Psychol 1997;65:733-9.

28 McLean I, Johnes M. Aberfan: government and disasters. Cardiff: Welsh Academic Press, 2000.

29 Morse J. Innovative inquiry [editorial]. Qual Health Res 2003;13:447-8.

30 Perrow C. Normal accidents. Princeton: Princeton University Press, 2003.

$$
\text { (Accepted } 11 \text { August 2005) }
$$

doi $10.1136 /$ bmj. 38603.375856 .68

Institute for Health Research, Lancaster University, Lancaster LA1 4YT

Maggie Mort senior lecturer

Josephine Baxter research associate

University of Central Lancashire

Ian Convery lecturer in human geography

International Centre for the Uplands, Lancaster University

Cathy Bailey research officer

Correspondence to: M Mort m.mort@lancaster.ac.uk 